\title{
E
}

51

.1392

vol.3

no. 2

NDIAN NOTES

NMAIREFD MONOGRAPHS

VOL. III

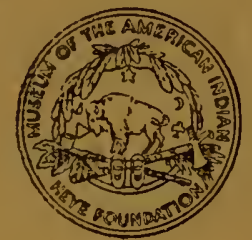

No. 2

A SERIES OF PUBLICATIONS REIAATING TO THE AMERICAN ABORIGINES

\section{THE AGE OF THE ZUNI PUEBLO OF KECHIPAUAN}

BY

F. W. HODGE

NEW YORE

MUSEUM OF THE AMERICAN INDIAN

HEYE FOUNDATION

1920 
Publications of the Museum of the American Indian, Heye Foundation

THE GEORGE G. HEYE EXPEDITION CONTRIBUTIONS TO SOUTH AMERICAN ARCHAEOLOGY

\section{Vol. 1}

The Antiquities of Manabi, Ecuador: A Preliminary Report. By Marshall H. Saville. 1907. $\$ 25.00$.

Vol. 2

The Antiquities of Manabi, Ecuador: Final Report. By Marshall H. Saville. 1910. $\$ 25.00$.

CONTRIBUTIONS FROM THE MUSEUM

OF THE AMERICAN INDIAN, HEYE FOUNDATION

\section{Vol. 1}

No. 1: Lucayan Artifacts from the Bahamas. By Theodoor de Booy. Reprinted from Amer. Anthropol., Vol. 15, 1913, No. 1. 50c.

No. 2: Precolumbian Decoration of the Teeth in Ecuador, with some Account of the Occurrence of the Custom in other parts of North and South America. By Marshall H. Saville. Reprinted from Amer. Anthropol., Vol. 15, 1913, No. 3. 50c.

No. 3: Certain Kitchen-middens in Jamaica. By Theodoor de Booy. Reprinted from Amer. Anthropol., Vol. 15, 1913, No. 3. (Reprinted, 1919.) 50c.

No. 4: Porto Rican Elbow-stones in the Heye Museum, with discussion of similar objects elsewhere. By J. Walter Fewkes. Reprinted from Amer Anthropol., Vol. 15, 1913, No.3. $50 \mathrm{c}$. 


\title{
INDIAN NOTES \\ AND MONOGRAPHS
}

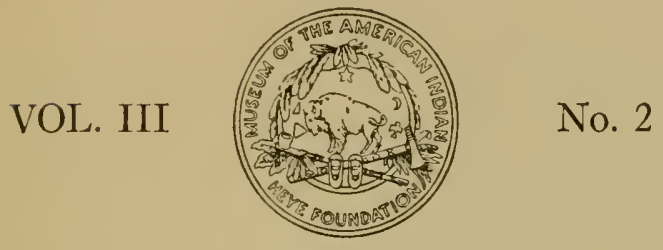

A SERIES OF PUBLICATIONS RELATING TO THE AMERICAN ABORIGINES

\section{THE AGE OF THE ZUNI PUEBLO OF KECHIPAUAN}

\author{
BY \\ F. W. HODGE
}

NEW YORK

MUSEUM OF THE AMERICAN INDIAN HEYE FOUNDATION 
This series of Indian Notes and MonoGRAPHS is devoted primarily to the publication of the results of studies by members of the staff of the Museum of the American Indian, Heye Foundation, and is uniform with Hispanic Notes and Monografhs, published by the Hispanic Society of America, with which organization this Museum is in cordial coöperation. 


\title{
THE AGE OF THE ZUÑI PUEBLO OF KECHIPAUAN
}

\author{
BY \\ F. IV. HODGE
}





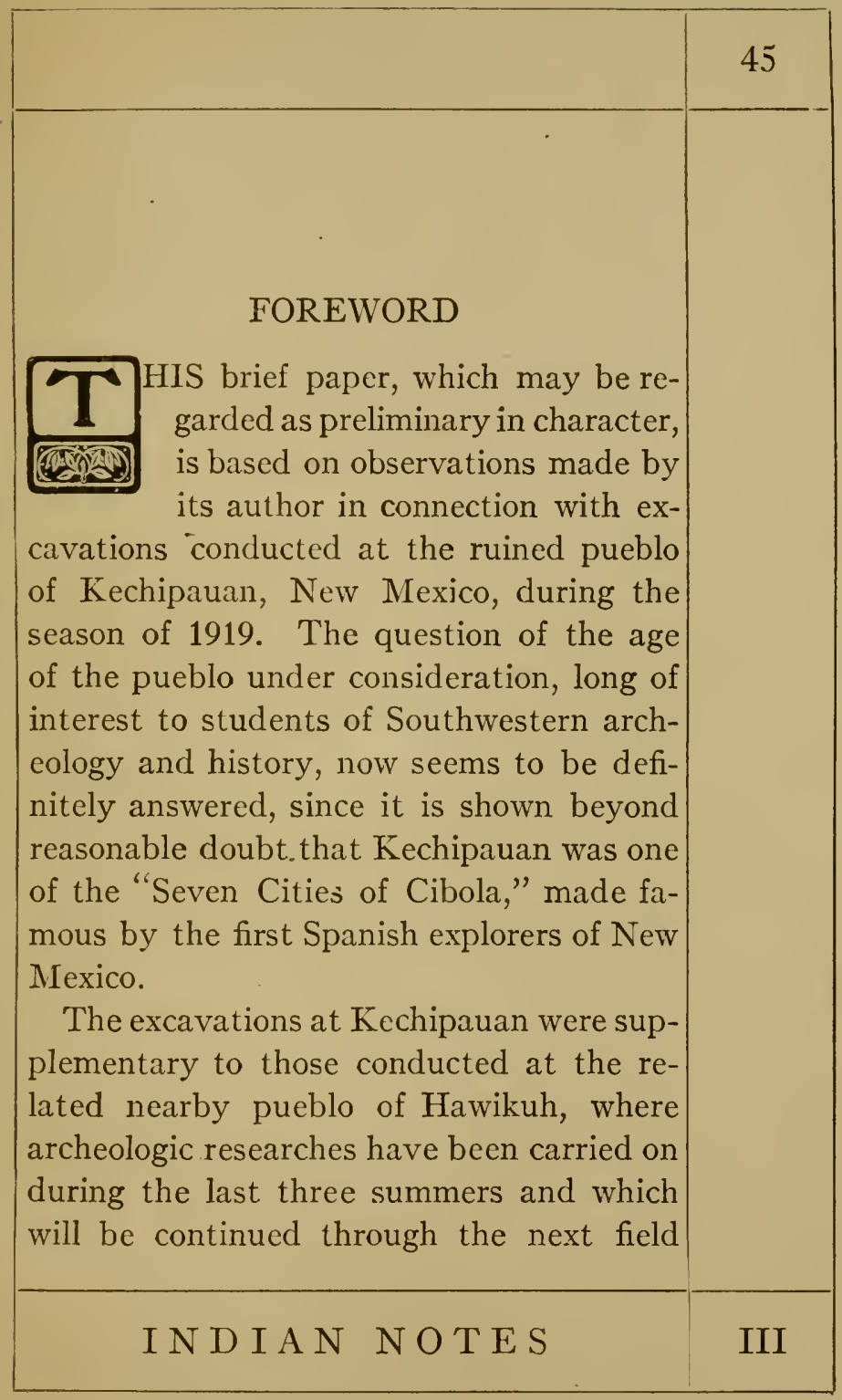




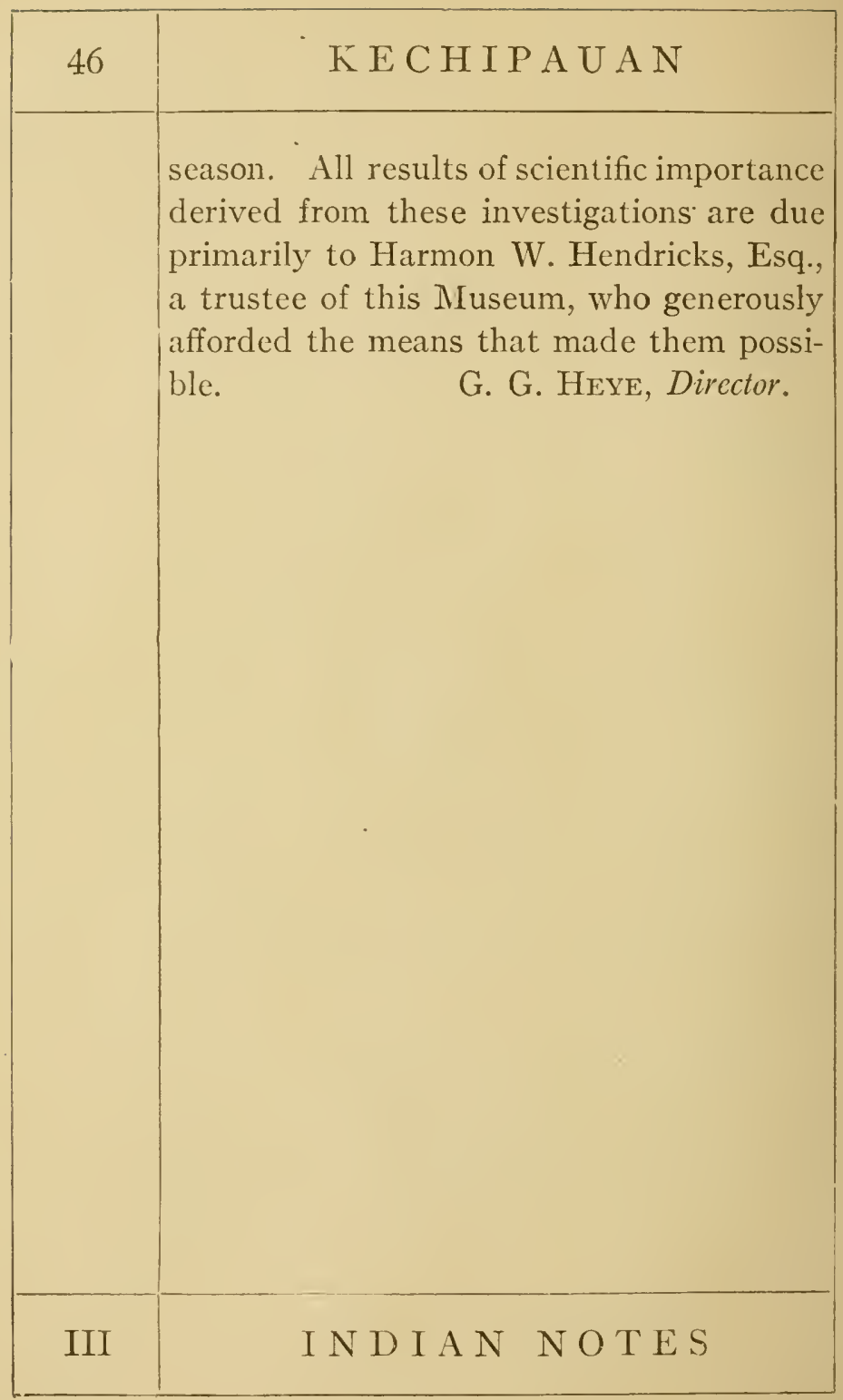





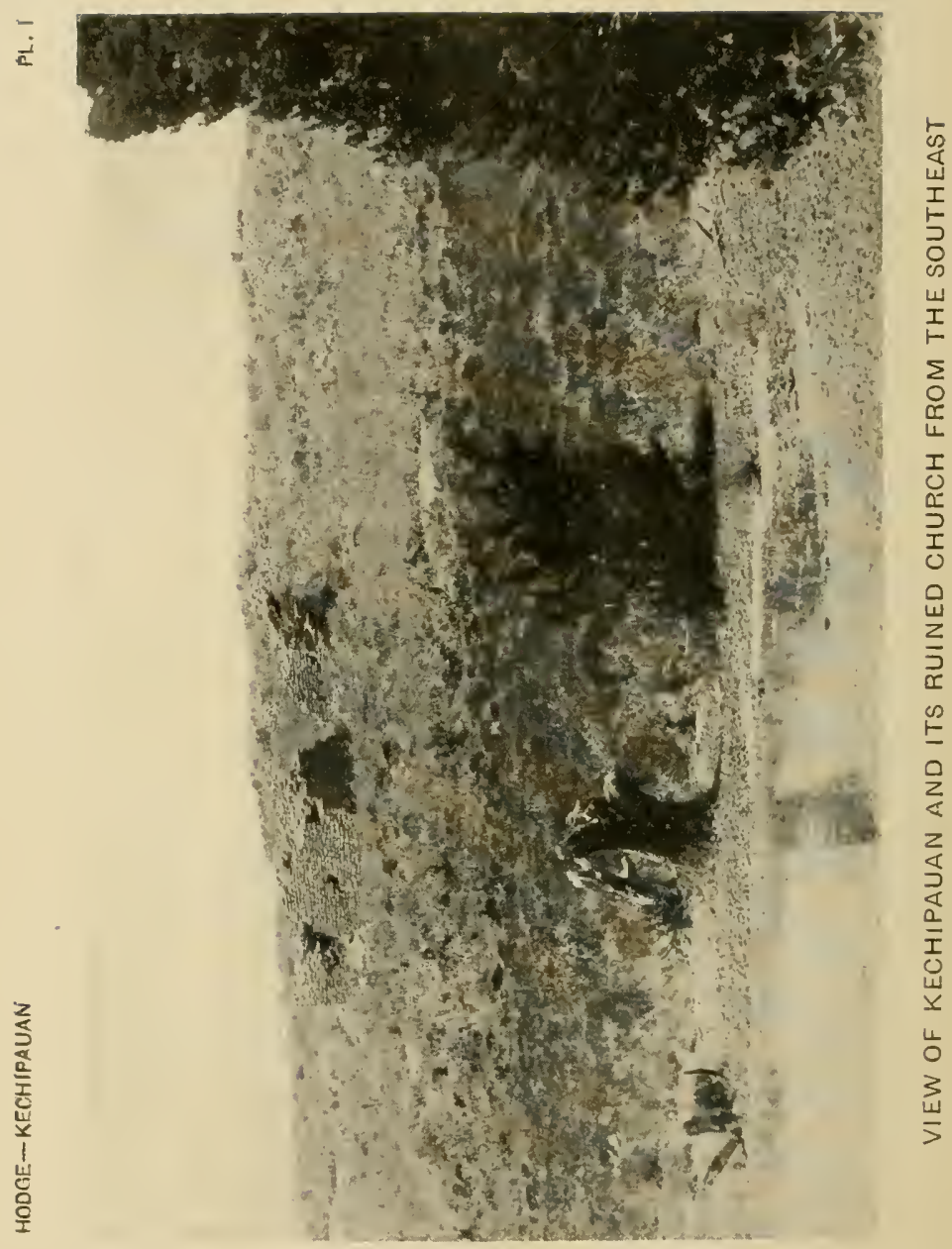




\title{
THE ÅGE OF THE ZUNI PUEBLO OF KECHIPAUAN
}

\author{
By F. W. Hodge
}

TR EChIPAUAN is a ruined pueblo, 1. situated on the summit of the long sandstone mesa that bounds the Ojo Caliente valley on the north about fifteen miles southwest of Zuñipueblo in western central New Mexico. The traceable walls cover an approximate area of 250 feet northwest-southeast by 315 feet northeast-southwest, but none of them now stands above the surface. Native tradition regarding the site is hazy and conflicting, but the Zuñi all agree that the ruins are not old, as compared with those of certain other pueblos in the Zuñi valley which they ascribe to their ancestors.

It is not the intention in this paper to review the early history of the "Seven Cities of Cibola," as this has hitherto been done 


\section{KE CHIP A U A N}

by Bandelier and the present writer; ${ }^{1}$ rather it is the purpose to attempt the elucidation of a point that has long been in question respecting the occupancy of Kechipauan at the time the Zuñi people were first visited by Spanish explorers in the first half of the sixteenth century. A suggestion of the occupancy of Kechipauan in 1540 is made by Coronado himself ${ }^{2}$ there is more direct documentary evidence dating from $1583^{3}$ and $1598,{ }^{4}$ while limited archeological excavation at the site during the summer of 1919 by the Hendricks Hawikuh Expedition of the Museum of the American Indian, Heye Foundation, affords verification of this historical testimony.

The first of the chroniclers mentioned states specifically that in 1540 another town was situated near Hawikuh, and indeed Kechipauan is not more than two and a half miles therefrom.

A fortunate record by Luxán, in connection with Espejo's journey of 1583, mentions the Zuñi pueblos as (1) Malaque, (2) Cuaquema, (3) Agrisco, (4) Oloná, (5) Cuaquina, and (6) Cana, which may be identi-

\section{NDIAN NOTES}





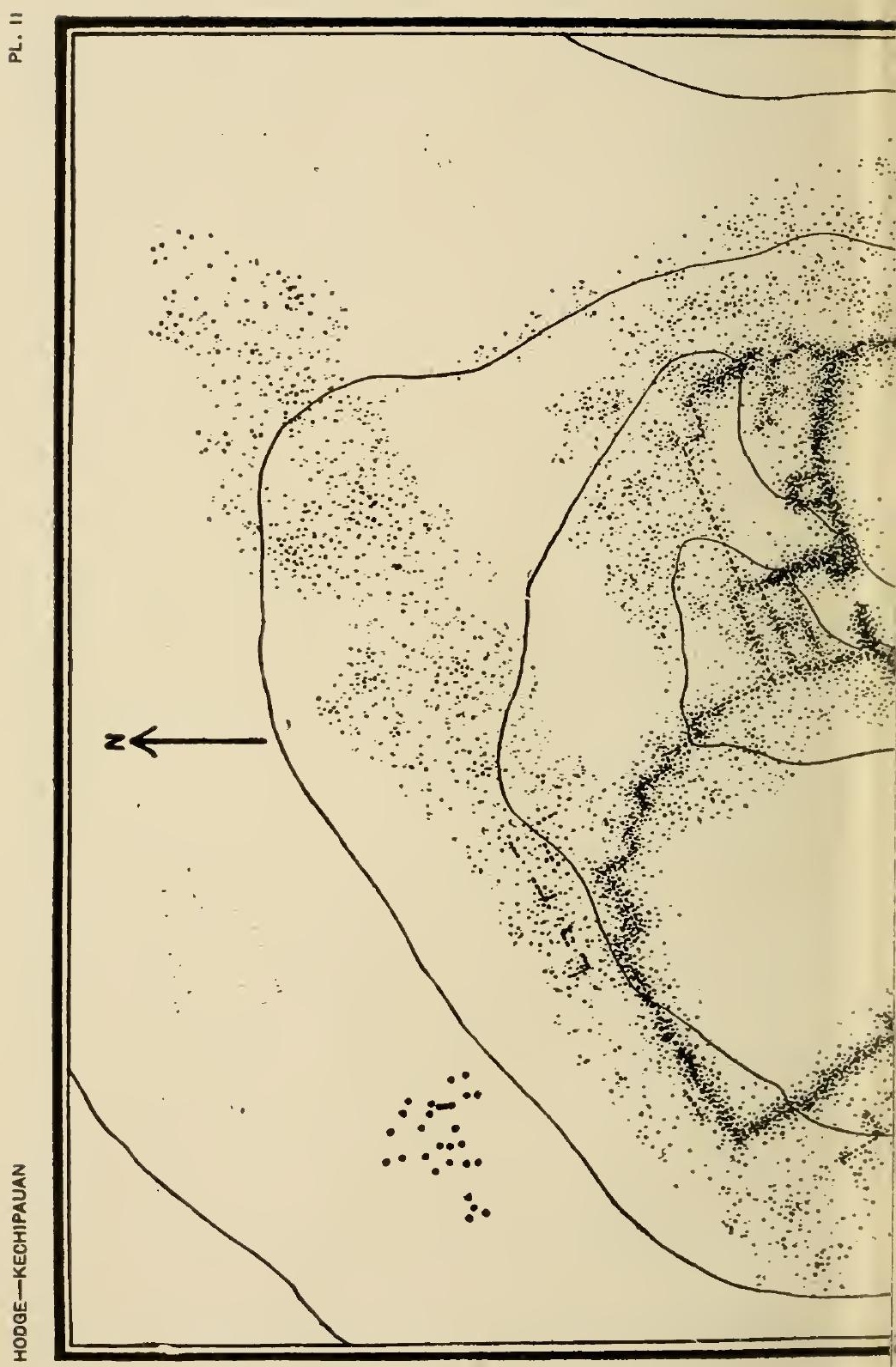




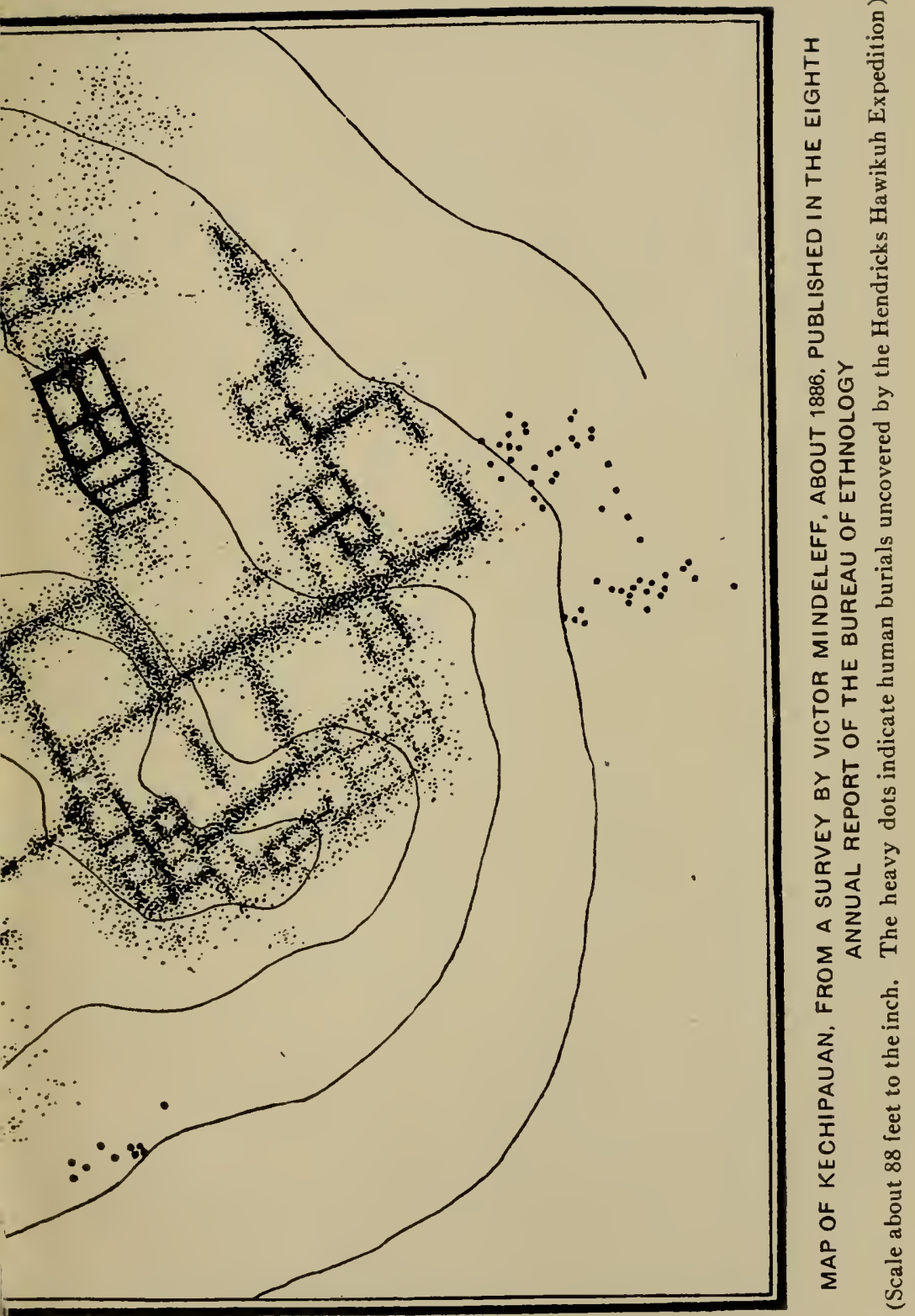





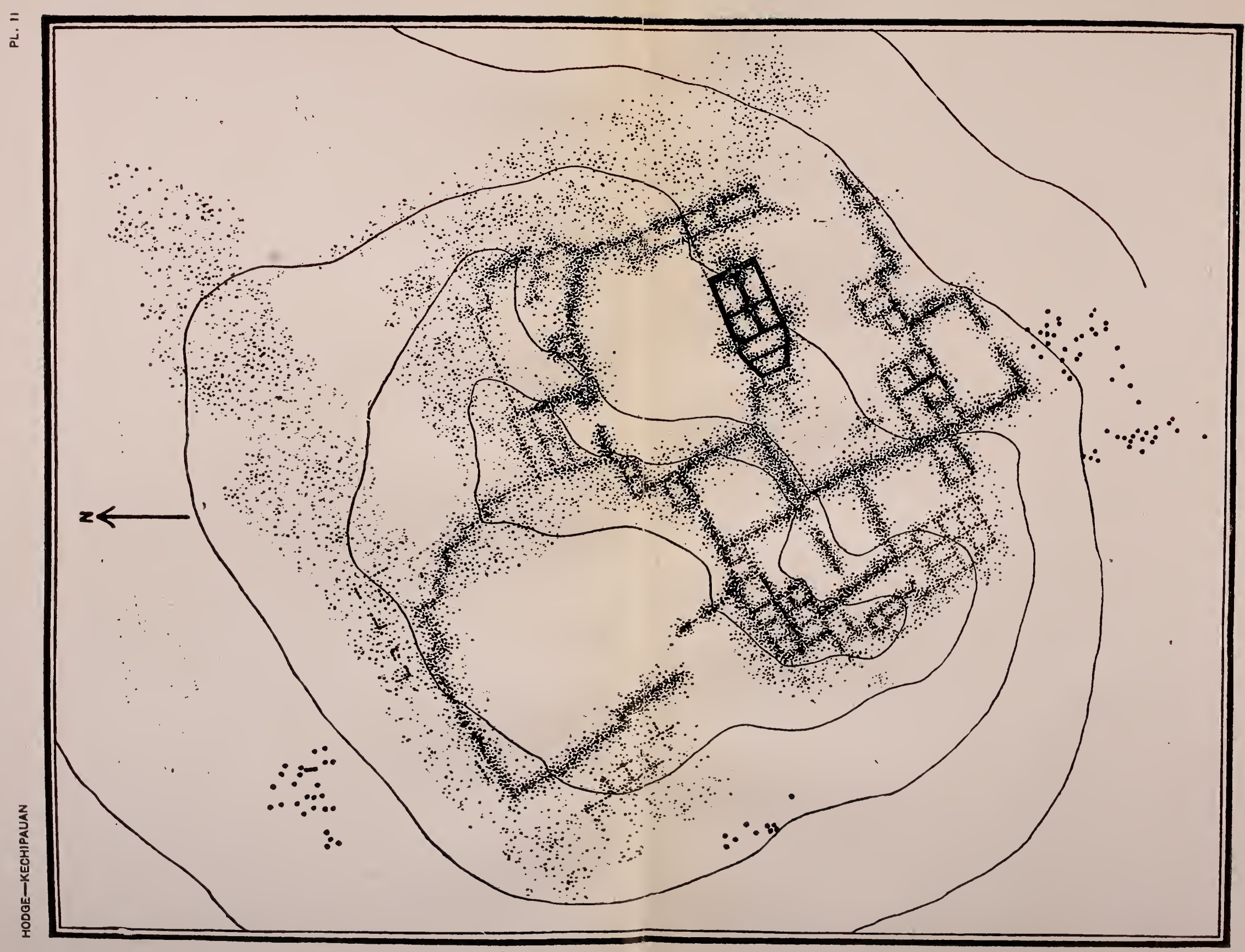

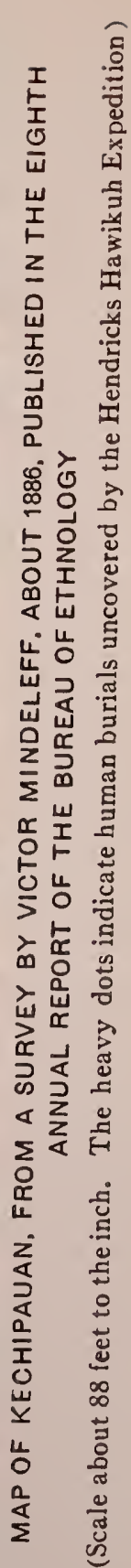





\section{K E C H P A U N}

fied with (1) Matsaki, (2) K'iakima, (3) Hawikuh, (4) Halona, (5) Kwakina, and (6) K'ianawe or Kechipanan, the name $\mathrm{K}$ 'ianawe referring to the Ojo Caliente neighborhood, while Kechipauan bears allusion to the gypsum-like sandstone of the mesa on which the ruins are situated (kéch$i p a=$ gypsum $),{ }^{5}$ in much the same way that the name Harwikuh refers to the "weedy place."

The names given in the official list of the Zuñi villages recorded by Onate in 1598 were doubtless much garbled by copying and printing in Documentos Inéditos (vol. $\mathrm{XVI}$ ), but there is no greater disparity between their orthography and the true forms than between the Espejo (Luxán) and Oñate lists. As printed from the Oñate document in the Spanish archives, we have: (1) Macaqui (Matsaki), (2) Coaqueria (K'iakima), (3) Aguicobi and Aguscobi (Hawikuh), (4) Halonagu (Halona), (5) Aquinsa (Kwakina), and (6) Canabi (K'ianawe or Kechipauan). Regarding Aquinsa, it must be said that there is no resemblance between the name and Kwakina, to be sure, and its

\section{A N D MONOGRAPH S}


identification with Kwakina is made solely by elimination, since we may hardly assume that a new pueblo had been established be. tween 1540 and 1598, at a period when the tendency of the Zuni was to abandon their villages rather than to increase their number. The identity of Aquinsa with Pinawa, or "Apinawa," is not acceptable, as Spier has already shown, by a study of the potsherds of that ruin, that Pinawa could hardly have been occupied at the time of the coming of the first Spaniards.

However, the pueblo of Kechipauan is the one that concerns us chiefly here, so we will defer further discussion of the other cities of Cibola until some future time. 'There is justification in the identification of the Cana of Espejo and the Canabi of Onate with $\mathrm{K}$ 'ianawe or Kechipauan, for historical reasons, although aside from Coronado's allusion to another pueblo near Granada-Hawikuh in 1540 , we have little more than rather remote resemblance of names on which to base such conclusion from the documentary point of view alone.

But native tradition and archeology both 



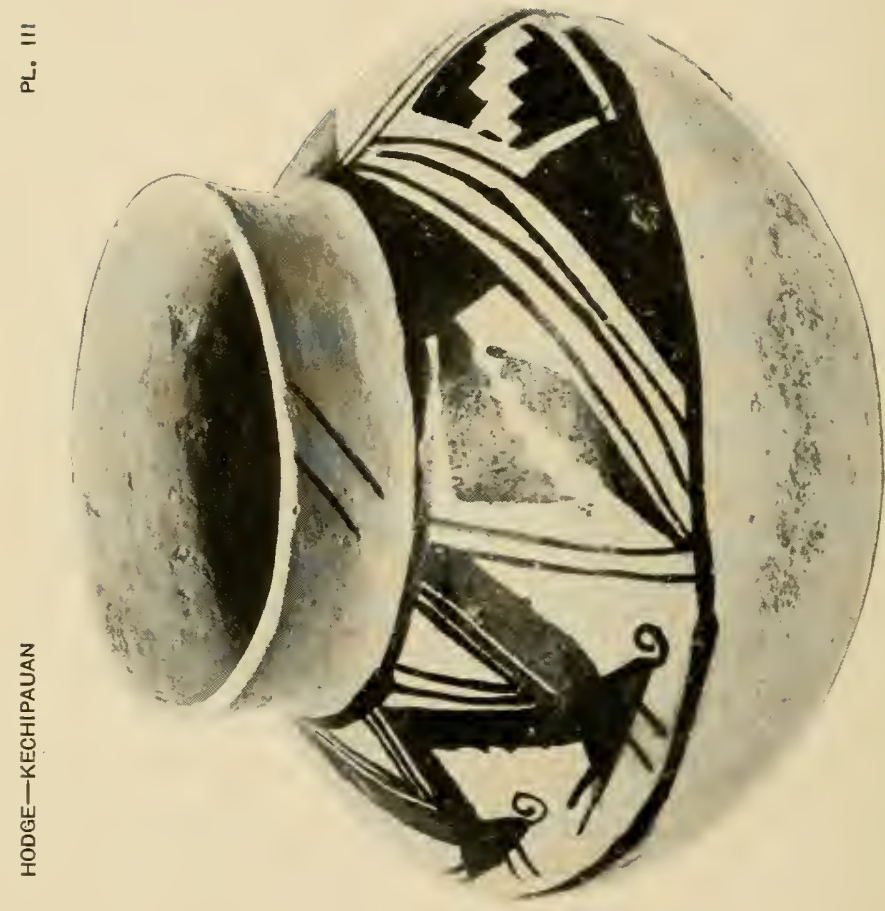

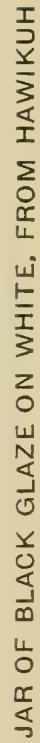


have a confirmatory story to tell. It has already been mentioned that Kechipauan belongs to a late period of Zuñi ruins according to the Zuñi themselves. On this point they are insistent. Moreover, the stone walls of a church at Kechipauan still stand several feet in height (pl. I), while the pueblo as a whole bears the appearance of having been inhabited during two distinct periods.

This is borne out by the excavations conducted in the refuse-heaps on the southern, western, and northwestern sides of the pueblo during the last field season (pl. II). As at nearby Hawikuh, the refuse of the pueblo was thrown beyond the houses, wherever convenient, and at Kechipauan it is especially deep on the southern side, where it extends to a maximum depth of about seven feet at a distance of 113 feet from the southwestern corner of the church. As at Ilawikuh likewise, the refuse deposits were used as the cemetery of the village, the eighty-six burials uncovered therein ranging in depth from just beneath the surface to exactly six feet. No work has yet been

A ND MONOGRAPHS 
conducted in the houses, the efforts of the expedition during the season of 1919, as during the previous two summers, being devoted chiefly to Hawikuh; but it is planned to extend excavation to the dwelling sites in the near future.

The work thus far done at Kechipauan shows no material difference in burial customs or in the artifacts accompanying the skeletal remains from those observed at Hawikuh. This is particularly true of the pottery, for while there are a few aberrant forms, as at Hawikuh, the earthenware of Kechipauan as a whole may be regarded as practically identical with that of its sister pueblo across the little valley to the westward (pl. III-VI). The periods of occupancy of Kechipauan were also doubtless the same as those of Hawikuh; in other words, the history of the two villages, so far as it is known, is virtually the same, if we may judge (1) by the slender documentary testimony pertaining to Kechipauan, (2) the uniformity in the burial custons, and (3) the similarity in the pottery found to accompany the dead. 



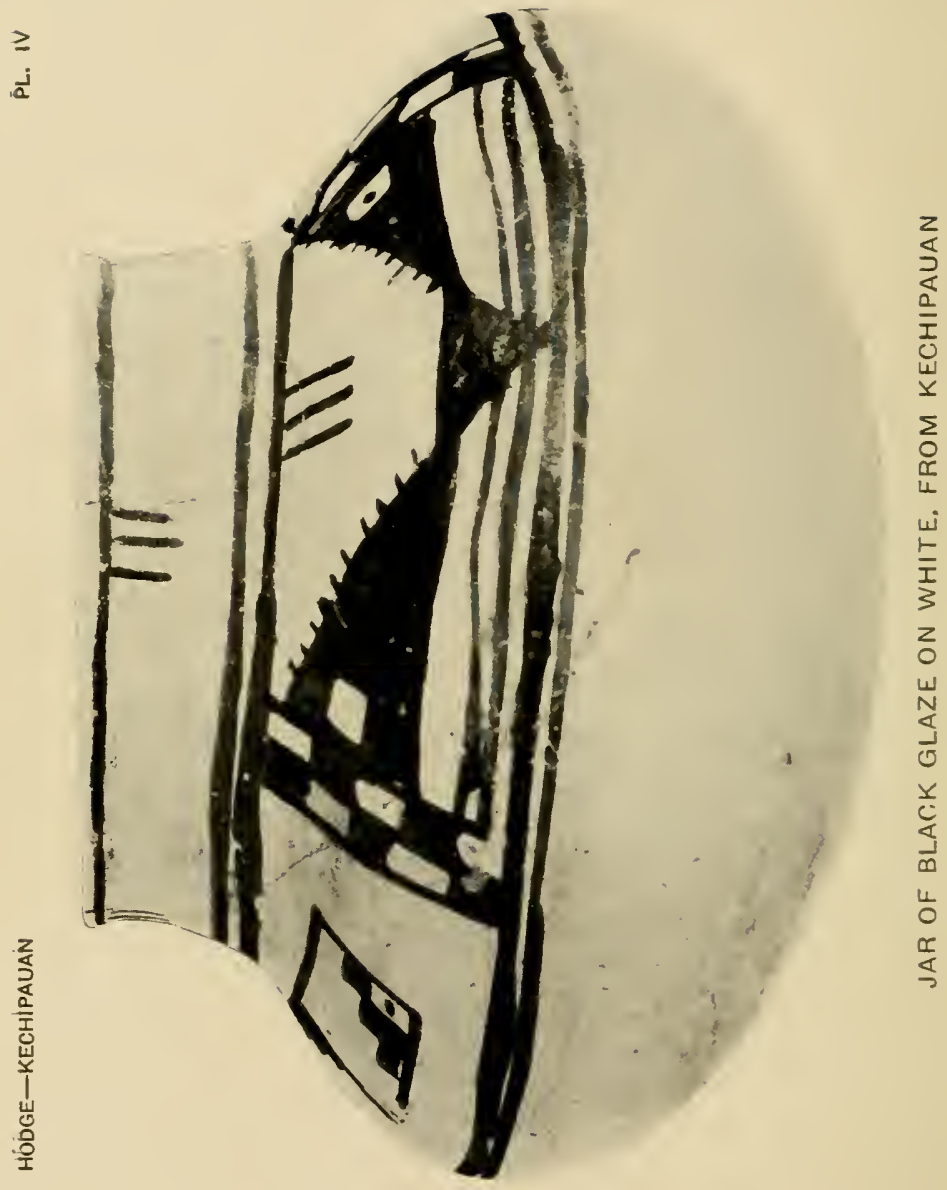


1. The historical allusions to Kechipauan have already been given, so far as needful at this time.

2. The chicf difference in the mortuary customs of the two pueblos lies in the fact that while at Hawikuh usually much food and various baskets that had contained food were deposited with the more recent dead, at Kechipauan there was usually a paucity of both. At both villages the remains interred in more recent times were directed eastwardly, for of the seventy burials (not including cremations) encountered at Kechipauan, thirty-two were directed toward the east, seventeen toward the northeast, and five toward the southeast, and similar orientation occurred at Hawikuh. At both sites the depth of the respective burials varied greatly, both ancient and recent interments having been made at greatly differing levels, regardless of the depth of the refuse; and at both sites, also, it was not the custom to bury the dead very near the houses, where the refuse was generally deeper. By reason of this fact the refuse-heaps of Kechipauan, in which

\section{A ND MONOGRAPHS}




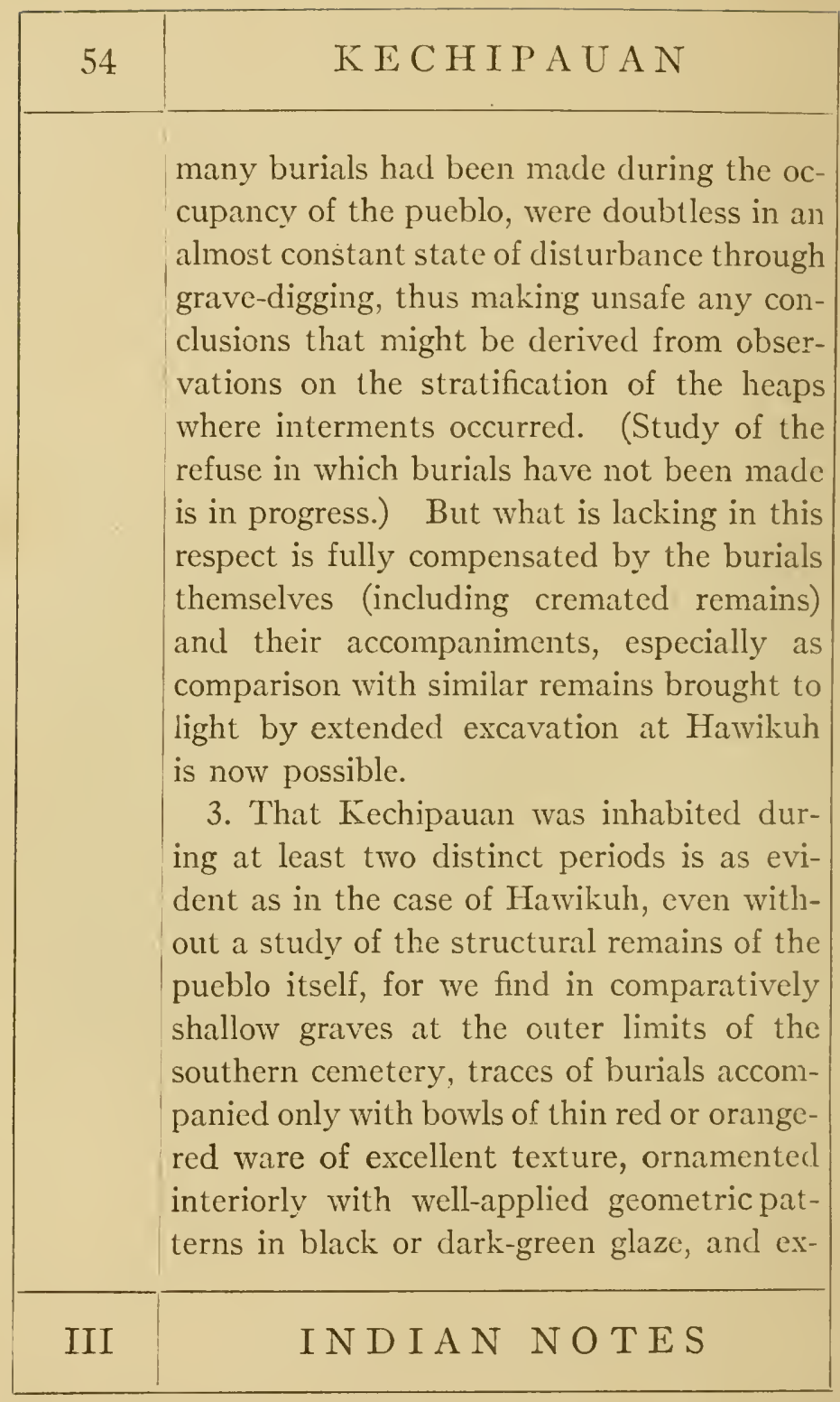


. 


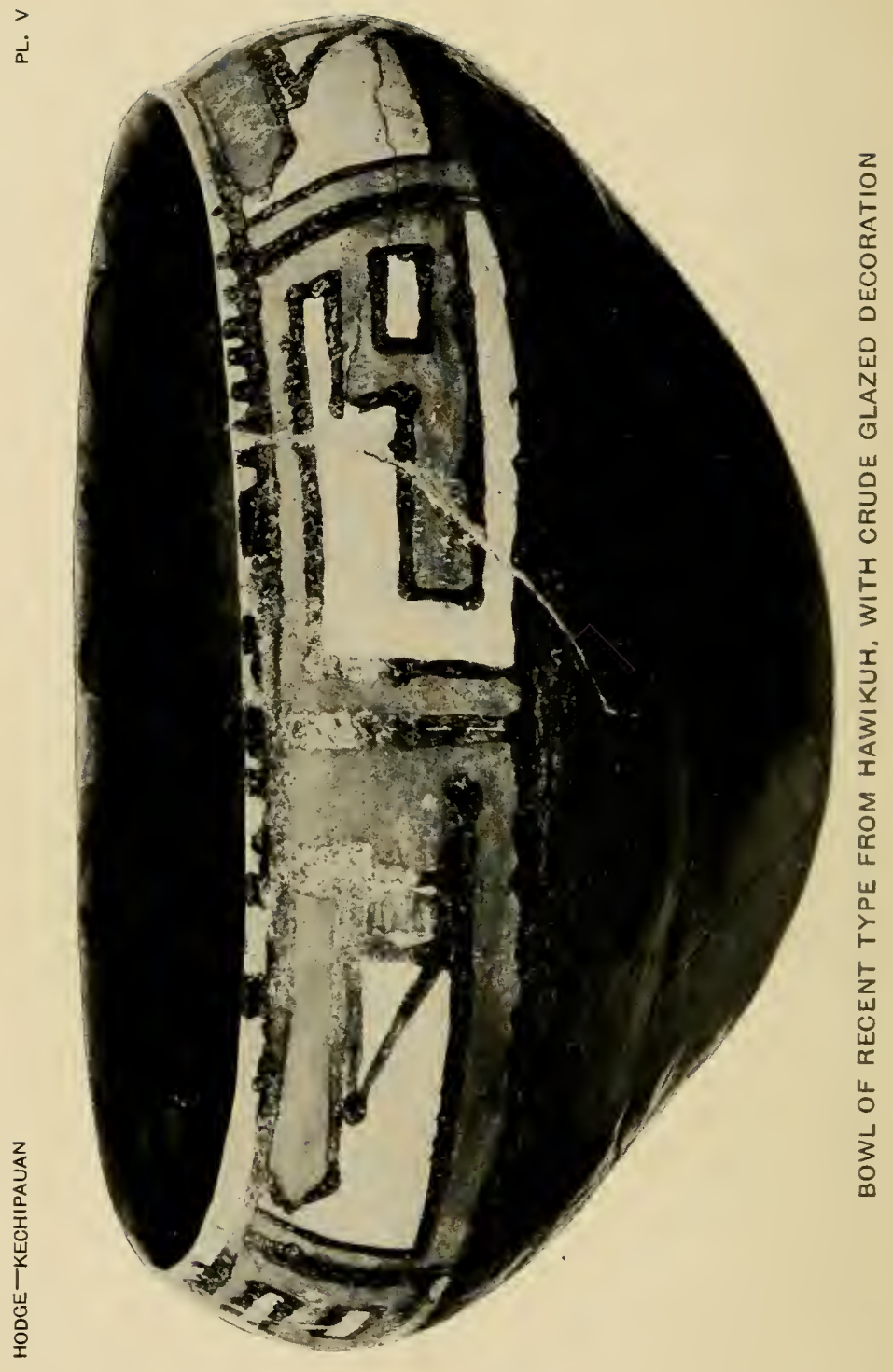


teriorly with a similar pattern beneath the rim in white non-glaze, so characteristic of the pottery in unquestionably prehistoric graves at Hawikuh. This excellent ware, limited in quantity at both pueblos, to be sure (as in the earliest times artifacts were not usually placed with the dead), was superseded, still in prehistoric times, by comparatively heavy pottery decorated with painted polychrome designs of conventionalized birds, or feathers, or of more lifelike zoömorphic forms, or with geometric or nondescript devices. After the introduction of the latter ware, or at least during the period of its use at the two pueblos referred to, two forms of burial were practised-inhumation and incineration, since polychrome ware is found both in graves, often in association with other artifacts, and as receptacles for cremated remains, the calcined bones having been placed with burned food, articles of personal arlornment, and sometimes bone and stone implements, in and oftentimes about a jar covered with a bowl, both vessels usually being "killed" at the time of interment by puncturing the bottom of

\section{AND MONOGRAPHS}




\begin{tabular}{|c|c|}
\hline 56 & K E C H I A U A N \\
\hline - & $\begin{array}{l}\text { each vessel, and sometimes the sides of the } \\
\text { containing vessel. It should here be said, } \\
\text { however, that at Kechipauan no cinerary } \\
\text { receptacles "killed" in this manner have } \\
\text { thus far been found. Of the numerous } \\
\text { earthenware receptacles found in association } \\
\text { with cremated remains at both Hawikuh } \\
\text { and Kechipauan, few indeed bear glazed } \\
\text { decoration. Examples of such are shown } \\
\text { in pl. III, IV. That the cremated remains } \\
\text { were deposited in prehistoric times is shown } \\
\text { by the fact that neither at Kechipauan nor } \\
\text { at Hawikuh has any article of European } \\
\text { manufacture been found in association with } \\
\text { the hundreds of cremations altogether } \\
\text { uncovered; moreover, the cinerary vessels } \\
\text { were placed in pits dug in the earth before } \\
\text { the superposed refuse from the houses had } \\
\text { accumulated to any considerable extent, } \\
\text { since the immediate strata of the latter, } \\
\text { which consist largely of ashes, were found } \\
\text { undisturbed in every instance. } \\
\text { That the polychrome ware was still in use, } \\
\text { if not actually made, both at Kechipauan } \\
\text { and at Hawikuh at the time of the coming } \\
\text { of the Spaniards in } 1540 \text {, or during the be- }\end{array}$ \\
\hline III & INDIAN NOTES \\
\hline
\end{tabular}





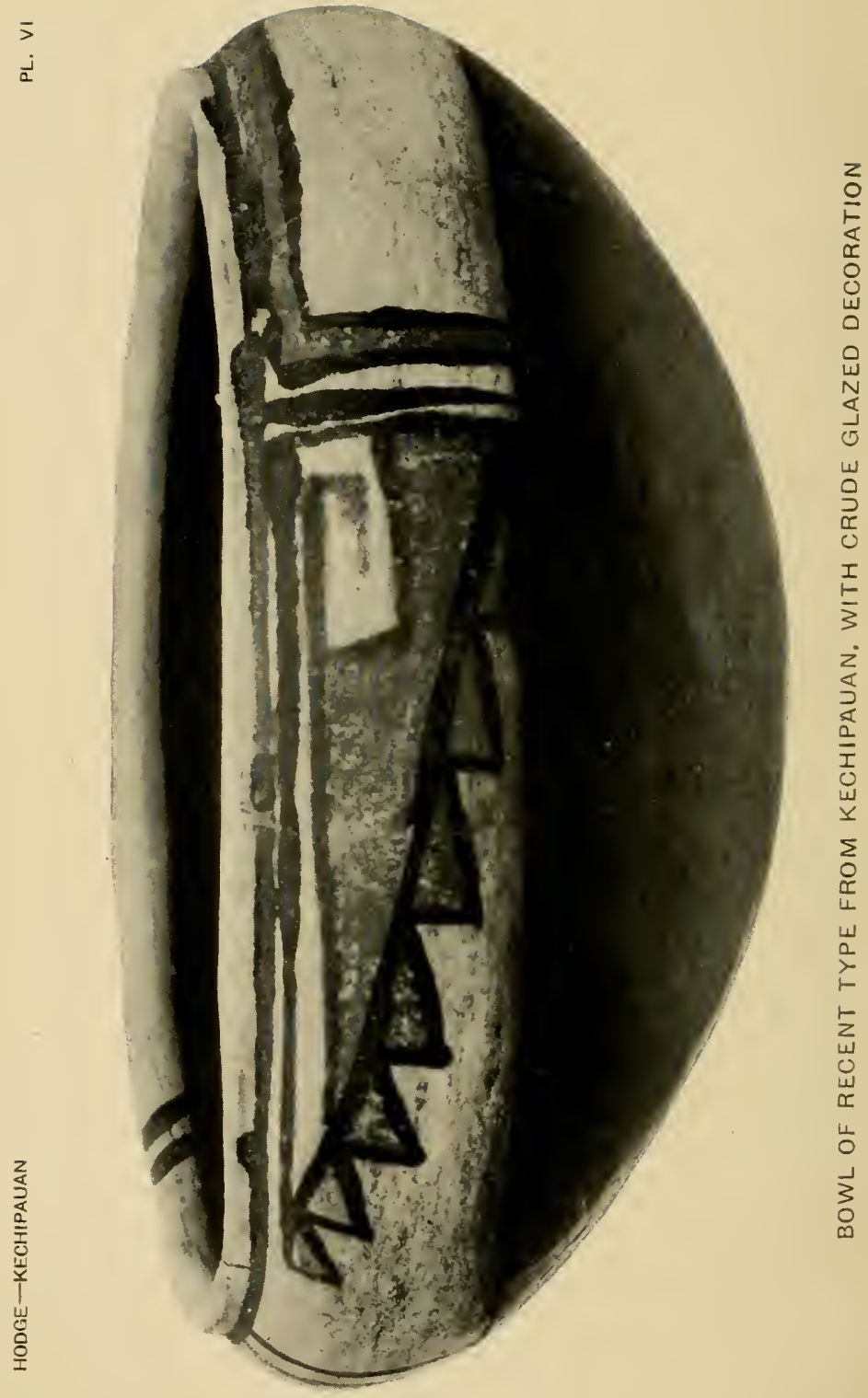


ginning of the mission period of the Zuni tribe in 1629 , is evident from the fact that it is found in graves in association with the third and most recent type of potterythin-walled vessels of fine hard ware, the ornamentation of which is characterized by a glaze, often in green and black, sometimes associated with red non-glaze, and consisting of both geometric and zoömorphic de$\operatorname{signs}(\mathrm{pl} . \mathrm{v}, \mathrm{vI})$. In this pottery the glazing is so crudely applied, evidently owing to noncontrol of the glazing material, that it may readily be distinguished from the neatly applied glaze decoration of the oldest ware to which we have referred. The bowls of this recent ware are never ornamented exteriorly with a geometric pattern in white, as in the case of the ancient bowls. Objects of European proveniance, such as articles of iron and copper, glass trade beads, bits of china, etc., are frequently found in graves in association with this recent glazed ware, and to a lesser extent with the polychrome ware, but no intrusive article has been found in connection with a grave in which the pottery accompaniments con-

A N D M O N G R A P H 
sisted of the earliest glazed bowls, nor in association with any of the cremated remains at either pueblo.

The finding of intrusive objects in the graves at Kechipauan is significant, for while it may be contended that the building of the church may have been commenced with a view to the rehabilitation of a pueblo long abandoned, or even to serve a new pueblo, we cannot deny the fact that the occurrence of articles of European manufacture in a number of the graves affords substantial evidence of the occupancy of the pueblo long after the coming of the Spaniards, and lends support to the identification of Kechipauan with the Cana of Espejo and the Canabi of Onate. If it be conjectured that Kechipauan was entirely built after the Spanish advent and that the European objects found in the graves may thus be accounted for, then the same would apply also to Hawikuh, whereas the history of Hawikuh from 1540 to the time of its abandonment in 1670 is well known. Moreover, that both Kechipauan and Hawikuh were occupied in prehistoric times is 
evident from the fact that beneath the houses occupied at the latter pueblo up to the time of its abandonment are found everywhere the remains of stone walls of much earlier structures, at the level of which the prevailing pottery is of the ancient glazed ware to which we have referred; and doubtless Kechipauan will show identical conditions, for similar ancient walls have already bcen encountered at the outer edge of the southern refuse-heap of that village, in association with which sherds of the most ancient earthenware were found.

\section{NO'TES}

1. Consult the bibliography in Spier, an Outline for a Chronology of Zuñi Ruins, Anthr. Papers Amer. Muss. Nat. Hist, XviI, pt. III, 1917. See also Hodge, Coronado's March to Quivira, in Brower, Harahey, pp. 29-73, St. Paul, 1899; The Memorial of Fray Alonso de Benavides, translated by Mrs. Edward E. Ayer, annotated by F. W. Hodge and C. F. Lummis, Chicago, 1916.

2. In his letter to the Viceroy MIendoza, written at Granada (Hawikuh), August 3, $15+0$, Coronado wrote: "The Seven Cities are seven little villages. They are all within a rarlius of five leagues [about $13 \frac{1}{2}$ miles, which is almost the exact distance from

\section{A N D MONOGRAPHS}




\begin{tabular}{|c|c|}
\hline 60 & $\mathrm{~K} \mathrm{E} \mathrm{CH}$ I P A U A \\
\hline & 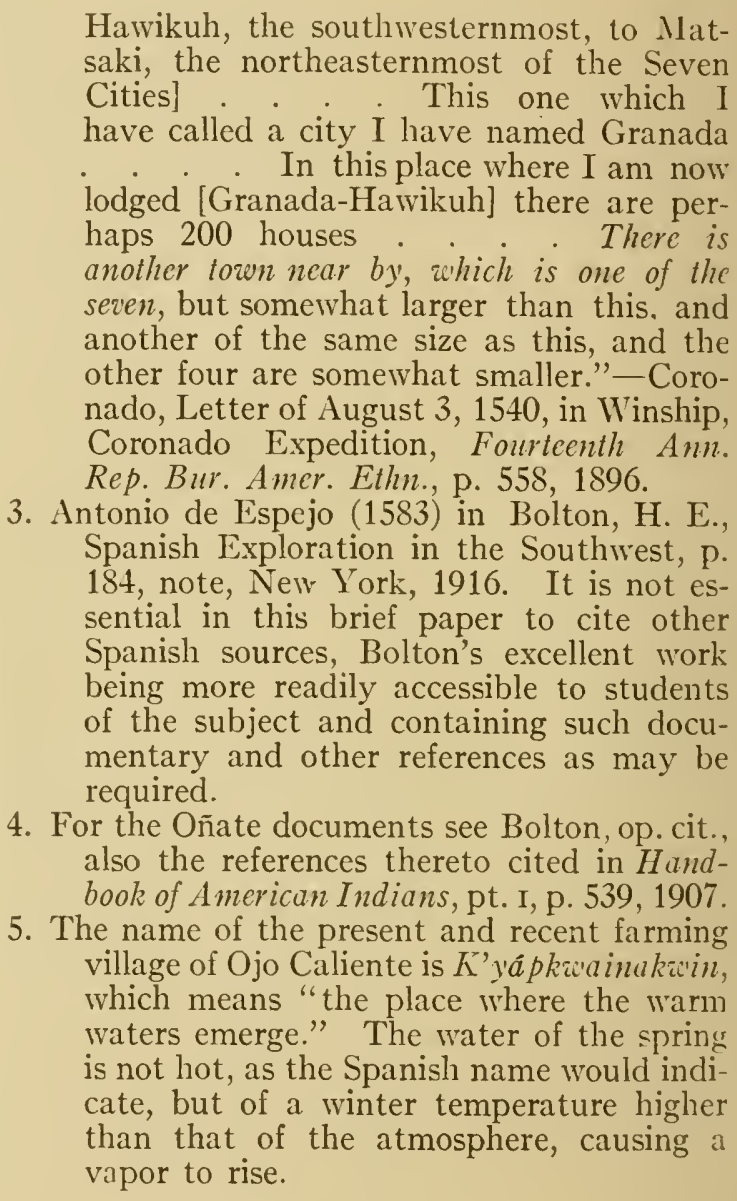 \\
\hline 111 & INDIAN NOTES \\
\hline
\end{tabular}


No. 5: Note on the Archaeology of Chiriqui. By George Grant MacCurdy. Reprinted from Amer. Anihropol., Vol. 15, 1913, No. 4. $50 \mathrm{c}$

No. 6: Petroglyphs of Saint Vincent, British West Indies. By Thomas Huckerby. Reprinted from Amer. Anthropol., Vol. 16, 1914. No. 2. 50c.

No. 7: Prehistoric Objects from a Shell-heap at Erin Bay, Trinidad. By J. Walter Fewkes. Reprinted from Amer. Anthropol., Vol. 16, 1914, No.2. 50c.

No. 8: Relations of Aboriginal Culture and Environment in the Lesser Antilles. By J. Walter Fewkes. Reprinted from Bull. Amer. Geogr. Soc., Vol. 46, 1914, No. 9, 50c.

No. 9: Pottery from Certain Caves in Eastern Santo Domingo, West Indies. By Theodoor de Booy. Reprinted from Amer. Anthropol., Vol. 17, 1915, No. $1.50 \mathrm{c}$.

\section{Vol. 2}

No. 1: Exploration of a Munsee Cemetery near Montague, New Jersey. By George G. Heye and George H. Pepper. 1915. \$1.00.

No. 2: Engraved Celts from the Antilles. By J. Walter Fewkes. 1915 . 50c.

No. 3: Certain West Indian Superstitions Pertaining to Celts. By Theodoor de Booy. Reprinted from Journ. Amer. Folk-Lore, Vol. 28, No. 107, 1915. 50c.

No. 4: The Nanticoke Community of Delaware. By Frank G. Speck. 1915. \$1.00.

No. 5: Notes on the Archeology of Margarita Island, Venezuela. By Theodoor de Booy. 1916. 50c.

No. 6: Monolithic Axes and their Distribution in Ancient America. By Marshall H. Saville. 1916. 50c. 


\section{Vol. 3}

Physical Anthropology of the Lenape or Delawares, and of the Eastern Indians in General. By Aleš Hrdlička. (Bur. of Amer. Ethnol., Bull. 62, 1916, with added title-page and cover.) \$1.00:

\section{Vol. 4}

No. 1: The Technique of Porcupine-Quill Decoration among the North American Indians. By William C. Orchard. 1916. $\$ 1.00$.

No. 2: Certain Archeological Investigations in Trinidad, British West Indies. By Theodoor de Booy. Reprinted from Amer. Anthropol., Vol. 19, 1917, No. 4. 50c.

No. 3: The Nacoochee Mound in Georgia. By George G. Heye, F. W. Hodge, and George H. Pepper. 1918. $\$ 1.50$.

\section{Vol. 5}

No. 1: A Letter of Pedro de Alvarado Relating to his Expedition to Ecuador [1534]. By Marshall H. Saville. 1917. 50c.

No. 2: The Diegueño Ceremony of the DeathImages. By E. H. Davis. $1919.50 \mathrm{c}$.

No. 3: Certain Mounds in Haywood County, North Carolina. By George G. Heye. Reprinted from Holmes Anniversary Volume, 1916. 1919. 50c.

No. 4: Exploration of Aboriginal Sites at Throgs Neck and Clasons Point, New York City. By Alanson Skinner. 1919. $\$ 1.00$.

\section{Address :}

Museum of the AmErican Indian, Heye

FOUNDATION,

BroadWAy at 155TH St.,

NEW YORK CITY 